\title{
Hubungan Antara Kepercayaan Diri dengan Hasil Belajar Matematika Berdasarkan Gender
}

\author{
Diah Rosa Septiani ${ }^{*}$,, \& Sigid Edy Purwanto ${ }^{2}$ \\ ${ }^{1,2}$ Universitas Muhammadiyah Prof. Dr. Hamka, Jakarta, Indonesia
}

\begin{tabular}{l} 
INFO ARTICLES \\
\hline Article History: \\
Received: $10-09-2020$ \\
Revised: $25-12-2020$ \\
Approved: $25-12-2020$ \\
Publish Online: $25-12-2020$ \\
\hline
\end{tabular}

Key Words:

Self Confidence; Mathematics Learning Outcomes; Gender;

(c) (†) (?)
This article is licensed
Shder a Creative Commons Attribution-
ShareAlike 4.0 International License.

\begin{abstract}
This study aims to determine how big is the relationship between self-confidence and mathematics learning outcomes of grade VIII students based on gender at SMP Negeri 5 Depok. The research method used is quantitative research methods with a correlational research design. The sample used was simple random sampling. In the validity test using Product Moment Correlation. Furthermore, the reliability test was carried out using theformula, it was Alpha Cronbach found that the instrument had a high reliability level. Furthermore, the data were analyzed the requirements test, namely the normality test using the Liliefors test. Error estimation Y against $X$ obtained homogeneous data. In the hypothesis test, ant-test was used independent sample with the conclusion that there was no difference in selfconfidence between male and female students. Then performed a hypothesis test using thecorrelation coefficient Pearson product momenttest and it can be concluded that there is a positive relationship between self-confidence and the mathematics learning outcomes of students.
\end{abstract}

\begin{abstract}
Abstrak: Penelitian ini bertujuan untuk mengetahui seberapa besar hubungan antara kepercayaan diri terhadap hasil belajar matematika peserta didik kelas VIII berdasarkan gender di SMP Negeri 5 Depok. Metode penelitian yang digunakan adalah metode penelitian kuantitatif dengan desain penelitian korelasional. Sampel yang digunakan adalah simple random sampling. Pada uji validitas dengan menggunakan Korelasi Product Moment. Selanjutnya dilakukan uji reliabilitas menggunakan rumus Alpha Cronbach diperoleh intrumen memiliki tingkat reliabel tinggi. Selanjutnya data dianalisis uji persyaratan yaitu uji normalitas menggunakan uji Liliefors Galat Taksiran Y terhadap X diperoleh data yang homogen. Pada uji hipotesis digunakan uji-t independent sample dengan kesimpulan tidak terdapat perbedaan kepercayaan diri antara peserta didik laki-laki dan perempuan. Kemudian dilakukan uji hipotesis menggunakan uji koefisien korelasi pearson product moment dan dapat disimpulkan bahwa terdapat hubungan yang positif antara kepercayaan diri dengan hasil belajar matematika peserta didik.
\end{abstract}

Correspondence Address: Jl. Tanah Merdeka No.20, RT.11/RW.2, Rambutan, Kec. Ciracas, Kota Jakarta Timur, DKI Jakarta 13830; e-mail: diahrosaseptiani@gmail.com

How to Cite (APA $6^{\text {th }}$ Style): Septiani, D.R., \& Purwanto, S.E. (2020). Hubungan Antara Kepercayaan Diri dengan Hasil Belajar Matematika Berdasarkan Gender. JKPM (Jurnal Kajian Pendidikan Matematika), 6(1): 141-148.

Copyright: 2020 Diah Rosa Septiani, Sigid Edy Purwanto

Competing Interests Disclosures: The authors declare that they have no significant competing financial, professional or personal interests that might have influenced the performance or presentation of the work described in this manuscript. 


\section{PENDAHULUAN}

Pendidikan merupakan suatu usaha yang dilakukan secara sadar untuk perubahan hidupnya yang sangat diperlukan dimasa yang akan datang. Sesuai dengan Undang-undang Sistem Pendidikan Nasional Republik Indonesia Nomor 20 Tahun 2003 Bab II Pasal 3 menyatakan bahwa tujuan pendidikan yaitu untuk mengembangkan kemampuan dan potensi yang dimiliki agar peserta didik menjadi manusia yang bertakwa kepada Tuhan Yang Maha Esa, berakhlak mulia, sehat, berilmu, cakap, kreatif, mandiri dan menjadi warga negara yang demokratis serta bertanggung jawab. Agar tercapainya tujuan pendidikan diatas maka pendidik harus mempunyai pengetahuan dan memahami bahwa setiap peserta didik memiliki sifat kepribadian yang berbeda, karena setiap peserta didik memiliki latar belakang dan lingkungan yang berbeda-beda dimana hal itu mempengaruhi kepribadian peserta didik diantaranya pembentukan kepercayaan dalam dirinya.

Pendidikan matematika memegang peranan penting dalam pembentukan karakter peserta didik. Matematika merupakan salah satu mata pelajaran yang menjadi dasar bagi ilmu pengetahuan yang lainnya karena di dalamnya terdapat kemampuan untuk berhitung, logika, dan berpikir (Faradhila et. al., 2013). Selain itu pengetahuan matematika merupakan alat penting dalam masyarakat yang dapat digunakan dalam kehidupan sehari-hari sehingga menjadikannya sebagai salah satu mata pelajaran yang harus dipelajari di sekolah. Pada kenyataannya, sebagian peserta didik kurang bersemangat ketika menghadapi pelajaran matematika. Matematika dianggap sebagai pelajaran yang sulit dan membosankan. Peserta didik cenderung merasa pesimis atau mudah menyerah saat tidak mampu menyelesaikan permasalahan matematika yang dianggap sulit sehingga peserta didik lebih cenderung percaya dengan hasil pekerjaan temannya. Selain itu, tidak semua peserta didik memiliki kepercayaan diri yang cukup dalam dirinya.

Ada dua faktor yang mempengaruhi hasil belajar menurut Dimyati dan Mudjiono dalam (Agustyaningrum \& Suryantini, 2017) yaitu faktor eksternal dan faktor internal. Faktor eksternal seperti guru sebagai pembina peserta didik belajar, sarana dan prasarana pembelajaran kebijakan penilaian, lingkungan sosial peserta didik di sekolah, dan kurikulum. Faktor internal terdiri dari sikap terhdap belajar, motivasi belajar konsentrasi belajar, menyimpan perolehan hasil belajar, menggali hasil belajar yang tersimpan, kemampuan berprestasi atau unjuk hasil belajar, rasa percaya diri peserta didik, intelegensi, kebiasaan belajar, dan cita-cita. Dari beberapa faktor internal yang disebutkan percaya diri merupakan salah satu faktor yang cukup kuat dalam mempengaruhi hasil belajar.

Kepercayaan diri merupakan suatu sikap positif sebagai modal dasar yang paling utama dalam diri seseorang untuk bisa mengembangkan kemampuan dirinya demi mencapai apapun yang diinginkan dan bisa dilakukan, baik terhadap diri sendiri maupun lingkungan atau situasi yang dihadapinya. Dengan memiliki kepercayaan diri peserta didik dapat mengembangkan minat, bakat dan potensi yang dimilikinya sehingga dapat mempengaruhi kesuksesan dalam belajar. . Indikator kepercayaan diri yang digunakan dalam penelitian ini yaitu: a) Percaya pada kemampuan sendiri; b) Berani mengungkapkan pendapat; c) Berani bertindak mandiri daam mengambil keputusan; d) Memiliki konsep diri yang hangat dan positif.

Menurut Aunurrahman dalam (Ningsih \& Sari, 2017) rasa percaya diri umumnya muncul ketika seseorang akan melakukan atau terlibat dalam suatu aktivitas tertentu dimana pikirannya terarah untuk mencapai suatu hasil yang diinginkannya. Rasa percaya diri dapat muncul dalam diri seseorang apabila memiliki keinginan untuk melakukan sesuatu sampai tujuan yang diinginkannya tercapai.

Dalam kemampuan matematika ada beberapa pernyataan negatif mengenai gender yang merugikan salah satu jenis kelamin khususnya perempuan. Pertama, perempuan kurang memiliki kemampuan yang baik dalam bidang STEM (Science, Technology, Engineering and Math). Perempuan dianggap kurang mampu untuk bertahan dalam bidang tersebut, karena dalam fakultas 
Teknik dan MIPA didominasi oleh laki-laki. Pernyataan seperti itu membuat perempuan kurang percaya diri untuk bisa menyelesaikan tugas yang diberikan sehingga membuat mereka menghindari tugas yang berhubungan dengan matematika.

Selanjutnya, Maloney, Waechter, Risko dan Fugeslang dalam (Fitriani, 2017) menunjukkan bahwa terdapat perbedaan kemampuan spasial antar perempuan dan laki-laki. Sementara Estes dan Felker dalam (Fitriani, 2017) mengatakan bahwa perbedaan kemampuan spasial antara laki-laki dan perempuan dimediasikan oleh kepercayaan diri.

Berdasarkan observasi yang penulis lakukan di SMP Negeri 5 Depok kelas VIII diperoleh informasi bahwa hasil belajar matematika di sekolah tersebut masih rendah. Data hasil belajar matematika peserta didik masih rendah, dapat dilihat dari hasil Penilaian Tengah Semester (PTS). Untuk lebih jelasnya data hasil belajar matematika peserta didik kelas VIII dapat dilihat pada Tabel 1.

\begin{tabular}{ccccc}
\multicolumn{5}{c}{ Tabel 1. Data Hasil Penilaian Tengah Semester (PTS) Genap Kelas VIII } \\
\hline Kelas & KKM & Tuntas \% & Tidak Tuntas \% & Rata-rata \\
\hline VIII.3 & 78 & $70,59 \%$ & $29,41 \%$ & 78,4 \\
VIII.9 & 78 & $41,18 \%$ & $58,82 \%$ & 75,5
\end{tabular}

Dari Tabel 1. dapat disimpulkan bahwa rata-rata nilai matematika yang diperoleh masih sangat jauh dari KKM. Berdasarkan wawancara singkat dengan seorang guru dan beberapa peserta didik kelas VIII SMP Negeri 5 Depok, menganggap matematika merupakan pelajaran yang sulit dimengerti dan membosankan, sehingga peserta didik kurang tertarik dan malas ketika mengikuti pmebelajaran. Kepercayaan diri peserta didik untuk belajar matematika masih kurang sehingga menyebabkan hasil belajar peserta didik rendah. Selain itu, kepercayaan diri peserta didik juga masih rendah dalam mengerjakan soal-soal yang diberikan oleh guru, menjawab pertanyaan guru, mengajukan pertanyaan atau berlatih menjelaskan hasil pekerjaan mereka kepada temannya dirasakan masih kurang baik peserta didik laki-laki maupun perempuan.

Pencapaian hasil belajar yang baik merupakan salah satu dari tujuan pembelajaran dari berbagai mata pelajaran. Hasil belajar peserta didik dalam pelajaran matematika yang baik merupakan harapan bagi semua orangtua, peserta didik maupun guru. Peserta didik dapat meningkatkan hasil belajar matematikanya salah satunya dengan meningkatkan kepercayaan dirinya dalam pelajaran matematika. Kepercayaan diri dapat muncul dengan sendirinya, ketika peserta didik merasa memiliki kemampuan dalam pelajaran matematika. Tugas guru mata pelajaran matematika untuk dapat menumbuhkan kemampuan dan kepercayaan diri yang dimiliki setiap peserta didik.

Dapat dilihat dari penelitian yang dilakukan Adhia \& Ardila, (2017) diperoleh data dengan koefisien korelasi ganda $\mathrm{Rx}_{1} \mathrm{x}_{2}=0,94$ dan koefisien determinannya 88,36\% yang berarti bahwa percaya diri peserta didik memberikan hubungan terhadap hasil belajar matematika sebesar $88,36 \%$ berdasarkan hasil analisis data dapat disimpulkan bahwa terdapat hubungan yang signifikan antara percaya diri dengan hasil belajar peserta didik di kelas VIII SMP Negeri 2 Kota Solok.

Berdasarkan uraian di atas, maka peneliti merumuskan masalah "Seberapa besar hubungan antara kepercayaan diri dengan hasil belajar matematika peserta didik kelas VIII berdasarkan gender di SMP Negeri 5 Depok". Penelitian ini bertujuan untuk mengetahui seberapa besar hubungan antara kepercayaan diri dengan hasil belajar matematika peserta didik kelas VIII berdasarkan gender. Sesuai dengan permasalahan dalam penelitian ini, maka hipotesis penelitian ini adalah:

$\mathrm{H}_{0}$ : Tidak terdapat hubungan yang positif antara kepercayaan diri dengan hasil belajar matematika berdasarkan gender peserta didik di SMP Negeri 5 Depok

$\mathrm{H}_{1}$ : Terdapat hubungan yang positif antara kepercayaan diri dengan hasil belajar matematika berdasarkan gender peserta didik di SMP Negeri 5 Depok. 


\section{METODE}

Penelitian mengenai hubungan antara kepercayaan diri dengan hasil belajar matematika peserta didik berdasarkan gender ini dilakukan di SMP Negeri 5 Depok yang berada di Beji Timur, Kecamatan Beji, Kota Depok, Jawa Barat 16422. Metode penelitian yang digunakan yaitu penelitian korelasional. Menurut Emzir (2017) penelitian korelasional menggambarkan suatu pendekatan umum untuk penelitian yang berfokus pada penaksiran pada kovariasi diantara variabel yang muncul secara alami. Dalam penelitian ini peneliti ingin mengukur seberapa besar hubungan antara kepercayaan diri dengan hasil belajar matematika perserta didik berdasarkan gender. Teknik pengumpulan sampel pada penelitian ini diacak dengan menggunakan teknik Simple Random Sampling. Semua peserta didik pada kelas terpilih menjadi sampel penelitian.

Populasi adalah totalitas semua nilai yang mungkin, baik hasil menghitung maupun pengukuran, kuantitatif maupun kualitatif, daripada karakteristik tertentu mengenai sekumpulan obyek yang lengkap dan jelas (Sudjana, 2005). Dalam penelitian ini yang dijadikan target populasi oleh peneliti adalah seluruh peserta didik kelas VIII SMP Negeri 5 Depok tahun ajaran 2019/2020 dan yang menjadi populasi terjangkaunya adalah peserta didik kelas VIII-8.

Menurut Arikunto (2003), sampel adalah sebagian atau wakil populasi yang diteliti. Sampel yang digunakan dalam penelitian ini sebanyak satu kelas dari seluruh kelas VIII SMP Negeri 5 Depok yaitu kelas VIII-8 yang berjumlah 34 peserta didik.

Selain melihat penyebaran data melalui daftar distribusi frekuensi, peneliti juga akan melihat kategori skor kepercayaan peserta didik berdasarkan Tabel 2.

\begin{tabular}{cc} 
Tabel 2. Kategorisasi Skor Item Kepercayaan Diri \\
\hline Kriteria Penilaian & Kategori \\
\hline lebih dari 44 & Sangat Tinggi \\
antara 34 sampai 44 & Tinggi \\
antara 23 sampai 33 & Rendah \\
kurang dari 23 & Sangat Rendah \\
\hline
\end{tabular}

\section{HASIL PENELITIAN}

Dalam penelitian korelasional ini, peneliti menelaah tentang hubungan antara dua variabel yang skor-skor data pengamatannya berbentuk numerik. Sesuai dengan langkah-langkah analisis data yang telah dilakukan terhadap hasil penelitian, maka diperoleh gambaran mengenai permasalahan yang dibahas dalam penelitian. Pada bab kajian teori telah diuraikan tentang hasil penelitian lain serta membandingkan dengan teori-teori. Melalui teori-teori yang membahas bahwa kepercayaan diri merupakan salah satu faktor yang dapat mempengaruhi hasil belajar matematika peserta didik. Tinggi rendahnya hasil belajar matematika peserta didik tidak terlepas dari tingkat kepercayaan diri peserta didik dalam mengikuti proses pembelajaran.

Penelitian ini dilaksanakan dengan menggunakan instrumen berupa skala kepercayaan diri, skala tersebut berisi butir-butir pernyataan mengenai rasa kepercayaan diri terhadap matematika. Skala tersebut digunakan untuk mengetahui tingkat kepercayaan diri peserta didik. sedangkan untuk hasil belajar dilihat melalui tes yang diberikan oleh peneliti secara online.

Peneliti menyusun instrumen kepercayaan diri sebanyak 20 butir pernyataan. Diperoleh 13 pernyataan valid dengan nilai rata-rata 36,47; median 37; modus 38; simpangan baku 13,909; dan varians 193,473. Berikut Gambar 1. menyatakan skor kepercayaan diri peserta didik: 


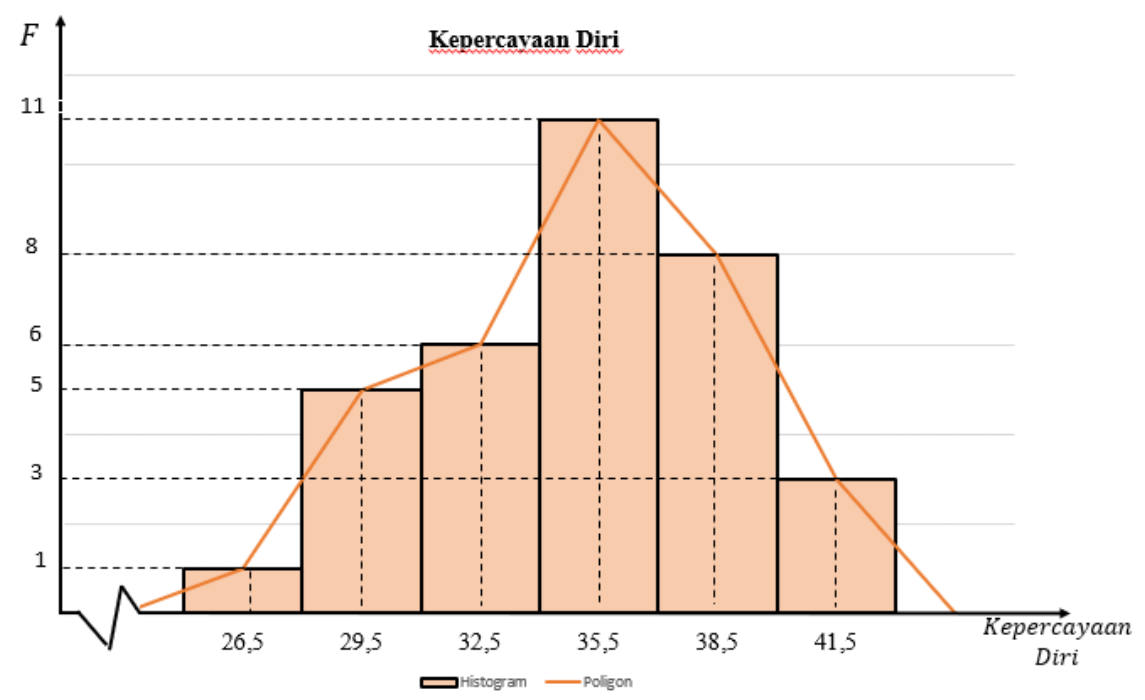

Gambar 1. Histogram dan Poligon Skor Rata-rata Kepercayaan Diri

Berdasarkan Gambar 1. terlihat bahwa sebagian besar peserta didik memiliki skor kepercayaan diri antara 36-38 sebanyak 11 peserta didik atau sebesar 32,35\%. Skor tertinggi berada pada rentang 42-44 sebanyak 3 orang atau sebeesar $8,82 \%$. Sementara skor terendah pada rentang 27-29 sebanyak 1 orang atau sebesar 2,94\%.

Hasil perhitungan data nilai kepercayaan diri peserta didik disajikan dalam Tabel 3.

\section{Tabel 3. Tabel Rentang Hasil Kepercayaan Diri Peserta Didik}

\begin{tabular}{ccc}
\hline Kriteria Penilaian & Frekuensi & Kategori \\
\hline lebih dari 44 & 0 & Sangat Tinggi \\
antara 34 sampai 44 & 25 & Tinggi \\
antara 23 sampai 33 & 9 & Rendah \\
kurang dari 23 & 0 & Sangat Rendah
\end{tabular}

Dari Tabel 3. rentang nilai, terlihat bahwa terdapat sebagian besar peserta didik mendapat skor kepercayaan diri dengan kategori baik, yaitu sebanyak 25 peserta didik. Skor dengan kategori rendah sebanyak 9 peserta didik.

Selanjutnya dari data hasil uji coba instrumen hasil belajar sebanyak 8 soal essay didapat bahwa terdapat 5 soal valid dan 3 soal tidak valid. Dari data tersebut diperoleh nilai rata-rata sebesar 76,62; median 77,5; modus 85; varians 844,311; simpangan baku 29,057. Selanjutnya Gambar 2. berikut menyatakan skor rata-rata hasil belajar matematika peserta didik.

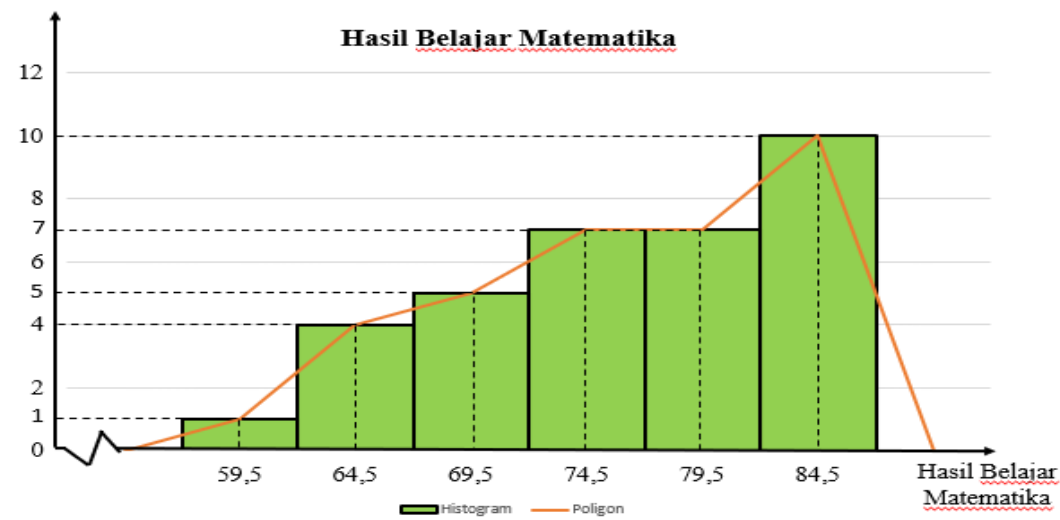

Gambar 2. Histogram dan Poligon Skor Rata-rata Hasil Belajar Matematika Peserta Didik 
Sebelum dilakukan pengujian hipotesis, dilakukan uji normalitas untuk mengetahu apakah data pada sampel yang diteliti berasal dari populasi yang berdistribusi normal atau tidak. Uji normalitas yang dilakukan menggunakan uji liliefors dan diperoleh hasil $L_{\text {hitung }}=0,077$, dengan demikian $L_{\text {hitung }}<L_{\text {tabel }}$ pada taraf signifikan 0,05. Sehingga, $H_{0}$ diterima dan dapat disimpulkan bahwa data berdistribusi normal.

Analisis regresi yang digunakan adalah regresi linier sederhana, didasarkan oleh hubungan fungsional antara variabel bebas (kepercayaan diri) dengan variabel terikat (hasil belajar matematika). Diperoleh harga konstanta (a) sebesar 27,21 dan koefisien arahnya (b) sebesar 1,35 Sehingga persamaan regresinya sebagai berikut:

$$
\widehat{Y}=27,21+1,35 X
$$

Arti dari persamaan (1), merupakan persamaan regresi, yaitu akan terjadi peningkatan hasil belajar matematika sebesar $1 \%$ disetiap 1,35 peningkatan kepercayaan diri dengan kondisi awal 27,21. Untuk menentukan linieritas regresi tersebut digunakan analisis varians (ANAVA). Dengan kriteria pengujiannya jika $F_{\text {hitung }} \leq F_{(k-2, n-k)}$, maka data variabel $\mathrm{X}$ linier terhadap $\mathrm{Y}$, dan sebaliknya jika $F_{\text {hitung }}>F_{\text {tabel }}$, maka data variabel X tidak linier terhadap Y.

Tabel 4. Analisis Varian (ANAVA) Linieritas Regresi

\begin{tabular}{ccccccc}
\hline Sumber Keragaman & DB & JK & KT & $F_{\text {hitung }}$ & $F_{\text {tabel }}$ & Keterangan \\
\hline Tuna Cocok (TC) & 13 & 213,89 & 16,45 & \multirow{2}{*}{0,05} & \multirow{2}{*}{$F_{13,19}=2,3$} & \multirow{2}{*}{$F_{\text {hitung }}<F_{\text {tabel }}$} \\
Kekeliruan (G) & 19 & 644,58 & 33,93 & &
\end{tabular}

Diperoleh hasil perhitungan analisis varians linieritas regresi $F_{\text {hitung }}=0,48$, dengan demikian $F_{\text {hitung }}<F_{\text {tabel }}$ pada taraf signifikan 0,05 . Sehingga, $H_{0}$ diterima dan dapat disimpulkan bahwa data variabel $\mathrm{X}$ linier terhadap variabel $\mathrm{Y}$.

Selanjutnya dilakukan uji keberartian regresi untuk menentukan keberartian model regresi tersebut digunakan analisis varians (ANAVA). Dengan kriteria pengujiannya adalah tolak $H_{0}$ jika $F_{\text {hitung }} \geq F_{(1-\alpha)(1, n-2)}$, maka model regresi berarti, dan sebaliknya jika $F_{\text {hitung }}<F_{\text {tabel }}$, maka model regresi tidak berarti.

Tabel 5. Analisis Varian (ANAVA) Keberartian Regresi

\begin{tabular}{lcccccc}
\hline \multicolumn{1}{c}{ Sumber Keragaman } & DB & JK & KT & $F_{\text {hitung }}$ & $F_{\text {tabel }}$ & Keterangan \\
\hline Regresi (a) & 1 & 199589 & & & & \\
Regresi ( $a \mid b)$ & 1 & 977,56 & 977,56 & 36,44 & 4,15 & $F_{\text {hitung }}>F_{\text {tabel }}$ \\
Residu (s) & 32 & 858,47 & 26,82 & & & \\
Total (t) & 34 & 201425 & & & & \\
\hline
\end{tabular}

Diperoleh perhitungan analisis varians keberartian regresi pada $F_{\text {hitung }}=36,44$, dengan demikian $F_{\text {hitung }} \geq F_{\text {tabel }}$ pada taraf signifikan 0,05 . Sehingga, $H_{0}$ ditolak dan dapat disimpulkan bahwa model regresi berarti.

Kemudian dilanjutkan untuk perhitungan uji hipotesis. Berdasarkan hasil perhitungan uji hipotesis menggunkan uji-t independent sample diperoleh $t_{\text {hitung }}=0,9877<t_{\text {tabel }}=2,04$ untuk (DB) 32 dan $\propto=0,975$ dimana $H_{0}$ diterima dapat disimpulkan bahwa tidak terdapat perbedaan kepercayaan diri antara peserta didik laki-laki dan perempuan. Selain itu, diketahui pula bahwa kepercayaan diri bisa mempengaruhi hasil belajar matematika. Dapat dilihat dari hasil uji hipotesis menggunkaan uji-t independent sample dengan diperoleh $t_{\text {hitung }}=4,2268>t_{\text {tabel }}=$ 2,04 untuk (DB) 32 dan $\propto=0,975$ dimana penolakan $H_{0}$ yang artinya terdapat perbedaan hasil belajar matematika peserta didik yang memiliki kepercayaan diri tinggi dan rendah. 
Dari dua hasil uji hipotesis di atas selanjutnya dilakukan uji korelasi pearson product moment untuk mengetahui apakah terdapat hubungan yang positif dan signifikan antara kepercayaan diri dan hasil belajar matematika berdasarkan gender. Setelah dilakukan uji korelasi pearson product moment diperoleh $r_{\text {hitung }}=0,731>r_{\text {tabel }}=0,2869$ untuk (DB) 32 dan $\propto=$ 0,05 sehingga penolakan $H_{0}$ yang membuktikan bahwa terdapat hubungan antara kepercayaan diri dengan hasil belajar matematika peserta didik berdasarkan gender namun termasuk kategori lemah pada kelas VIII-8 SMP Negeri 5 Depok. Hal tersebut dapat dilihat dari besarnya kontribusi variabel $\mathrm{X}$ terhadap variabel $\mathrm{Y}$ sebesar 53,4\%. Dengan demikian masih ada 46,6\% faktor lain yang dapat mempengaruhi hasil belajar matematika peserta didik khususnya materi bangun ruang selain dari kepercayaan diri seperti misalnya kondisi ketika mengerjakan tes, tingkat penguasaan materi, motivasi belajar, minat belajar dan faktor lainnya.

\section{PEMBAHASAN}

Berdasarkan hasil penelitian yang telah diperoleh, dapat disimpulkan bahwa kepercayaan diri memiliki hubungan dengan hasil belajar matematika peserta didik berdasarkan gender sebesar $53,4 \%$. Hal ini disebabkan karena peserta didik yang memiliki kepercayaan diri yang rendah terhadap pelajaran matematika akan berusaha untuk lebih memahami pelajaran matematika.

Hasil penelitian tersebut diperkuat dengan penelitian Adhia \& Ardila (2017) dari Universitas Mahaputra Muhammad Yamin, Solok dengan judul Hubungan Rasa Percaya Diri Terhadap Hasil Belajar Matematika Peserta didik Kelas VIII SMP Negeri 2 Kota Solok. Dari hasil penelitian yang dilakukan dapat disimpulkan bahwa terdapat hubungan yang signifikan antara percaya diri dengan hasil belajar peserta didik di kelas VIII SMP Negeri 2 Kota Solok.

Penelitian yang dilakukan oleh Adhia \& Ardila (2017) hanya dilihat hubungan antara percaya diri dengan hasil belajar matematika peserta didik. Oleh karena itu, perlu adanya tambahan atau pembaruan. Penelitian ini tidak hanya meninjau seberapa besar hubungan antara kepercayaan diri peserta didik dengan hasil belajar matematika saja, namun juga dilihat apakah gender dapat mempengaruhi tingkat kepercayaan diri peserta didik.

Sesuai dengan hasil dua penelitian di atas dapat ditarik kesimpulan bahwa kepercayaan diri memiliki hubungan dengan hasil belajar matematika peserta didik. Ternyata tidak terdapat perbedaan tingkat kepercayaan diri yang dimiliki antara peserta didik laki-laki dan perempuan yang mempengaruhi hasil belajar matematika.

Dari perspektif gender, untuk variabel yang lain, fakta penelitian juga menunjukkan bahwa tidak ada pengaruh yang signifikan. Hal ini dapat ditemukan dalam hasil penelitian Fitriani (2017), tidak terdapat perbedaan signifikan antara self efficacy peserta didik laki-laki dan perempuan.

Melalui penelitian ini, dan penelitian yang sudah dilakukan, memberikan gambaran bahwa kepercayaan diri memiliki sumbang sih dalam keberhasilan penerimaan konsep ataupun materi belajar. Terlebih dalam situasi pembelajaran daring (online), mental kuat dengan kepercayaan diri diperlukan sehingga peserta didik mampu menumbuhkan potensinya secara mandiri. Percaya diri bahwa mampu belajar mandiri, mampu mengambil inisiatif untuk melakukan/mencoba menyelesaikan masalah matematika sendiri. Sedangkan dalam perspektif gender, peserta didik laki-laki dan perempuan memiliki potensi kemampuan yang sama. Dengan demikian, pembedaan/perlakuan khusus terhadap masing-masing gender, tidak perlu dilakukan.

\section{SIMPULAN}

Berdasarkan hasil penelitian yang telah dilakukan, maka dapat disimpulkan bahwa tingkat rasa percaya diri peserta didik dalam belajar matematika dengan rata-rata 36,47 adalah $32,3 \%$ peserta didik yang memiliki rasa kepercayaan diri di bawah rata-rata dan sebanyak $67,7 \%$ peserta didik yang memiliki rasa kepercayaan diri di atas rata-rata. Selanjutnya, sesuai perhitungan uji 
hipotesis didapat bahwa kepercayaan diri memiliki hubungan dengan hasil belajar matematika peserta didik berdasarkan gender sebesar sebesar 53,4\%. Selain itu, dari uji hipotesis yang dilakukan dapat diketahui bahwa tidak terdapat perbedaan kepercayaan diri antara peserta didik laki-laki dan perempuan dan terdapat perbedaan hasil belajar antara peserta didik yang memiliki kepercayaan diri yang tinggi dan rendah. Adapun saran-saran untuk penelitian selanjutnya yaitu meneliti hubungan antara kepercayaan diri peserta didik dengan hasil belajar secara umum, tidak berdasarkan faktor-faktor yang mempengaruhi kepercayaan diri. Kemudian peneliti bisa melibatkan subjek penelitian dengan jumlah yang lebih banyak.

\section{DAFTAR RUJUKAN}

Adhia, H., \& Ardila, D. (2017). Hubungan Percaya Diri Siswa Terhadap Hasil Belajar Matematika Siswa Kelas VIII SMP Negeri 2 Kota Solok. 2(1), 637915.

Agustyaningrum, N., \& Suryantini, S. (2017). Hubungan Kebiasaan Belajar Dan Kepercayaan Diri Dengan Hasil Belajar Matematika Siswa Kelas Viii Smp N 27 Batam. JIPMat, 1(2). https://doi.org/10.26877/jipmat.v1i2.1242

Faradhila, N., Imam, S., \& Yemi, K. (2013). Eksperimentasi Model Pembelajaran Missouri Mathematics Project (MMP) Pada Materi Pokok Luas Permukaan Serta Volume Prisma Dan Limas Ditinjau Dari Kemampuan Spasial Siswa Kelas VIII Semester Genap SMP Negeri 2 Kartasura Tahun Ajaran 2011/2012. Jurnal Pendidikan Matematika Solusi UNS, 1(1), 67-74.

Fitriani, W. (2017). "Analisis Self-Efficacy Dan Hasil Belajar Matematika Siswa Di Man 2 Batusangkar Berdasarkan Gender." Agenda, 1(1), 141-158.

Ningsih, G., \& Sari, R. N. (2017). Hubungan Rasa Percaya Diri Dan Kebiasaan Belajar Terhadap Hasil Belajar Matematika Siswa Kelas Ix Smp Negeri 16 Batam Tahun Pelajaran 2016/2017. PYTHAGORAS: Jurnal Program Studi Pendidikan Matematika, 6(1), 78-84. https://doi.org/10.33373/pythagoras.v6i1.1038 